\section{EMBRYRIDDLE \\ Aeronautical University}

SCHOLARLY COMMONS
International Journal of Aviation, Aeronautics, and Aerospace

\title{
Pilot Perceptions on Impact of Crew Rest Regulations on Safety and Fatigue
}

\author{
Lukas Rudari \\ Purdue University, Irudari@purdue.edu \\ Mary E. Johnson \\ Purdue University, mejohnson@purdue.edu \\ Robert C. Geske \\ Purdue University, robert.geske@aopa.org \\ Lauren A. Sperlak \\ Purdue University, LSperlak@purdue.edu
}

Follow this and additional works at: https://commons.erau.edu/ijaaa

Part of the Air and Space Law Commons, Aviation Safety and Security Commons, Health Law and Policy Commons, Human Resources Management Commons, and the Transportation Commons

\section{Scholarly Commons Citation}

Rudari, L., Johnson, M. E., Geske, R. C., \& Sperlak, L. A. (2016). Pilot Perceptions on Impact of Crew Rest Regulations on Safety and Fatigue. International Journal of Aviation, Aeronautics, and Aerospace, 3(1). https://doi.org/10.15394/ijaaa.2016.1096

This Article is brought to you for free and open access by the Journals at Scholarly Commons. It has been accepted for inclusion in International Journal of Aviation, Aeronautics, and Aerospace by an authorized administrator of Scholarly Commons. For more information, please contact commons@erau.edu. 
In June 2008, the National Transportation Safety Board (NTSB) issued a recommendation urging the Federal Aviation Authority (FAA) to "develop guidance, based on empirical and scientific evidence, for operators to establish fatigue management systems, including information about the content and implementation of these systems" (National Transportation Safety Board, 2008, p. 10). The NTSB stated that it took this step based on "longstanding concerns about human fatigue causing or contributing to aviation accidents and/or incidents" (NTSB, 2008, p. 3) and the inadequacy of existing regulation at mitigating fatigue risks in aviation.

The Air Line Pilots Association [ALPA] (2008a), a large U.S. and Canadian pilot union, commended NTSB for its work in the area of airline pilot fatigue, signaling that unions are concerned that pilot fatigue poses a risk to safety in aviation. The organization highlighted that any solution to combat pilot fatigue would have to be successfully included in corporate cultures and corporate fatigue risk management systems (Air Line Pilots Association, 2008a).

The safety risk of pilot fatigue became more apparent after two recent major aviation accidents. Colgan Air flight 3407 crashed on February 12, 2009, about 2217 Eastern Standard Time (EST). While the NTSB did not identify fatigue as a contributing factor to the accident, recommendations were made in the final accident report to improve the fatigue risk management system (FRMS) in place at Colgan Air (NTSB, 2010). UPS flight 1354 crashed on August 14, 2013, about 0447 Central Daylight Time (CDT). NTSB (2014) found that both the captain's and first-officer's flight performance was impaired due to fatigue and circadian factors.

In 2012, the Federal Aviation Administration (FAA) made changes to the previous rest requirements in the form of Title 14 Code of Federal Regulations Part 117 (Part 117) for passenger operations to address fatigue-related risks factors for airline pilots. The rule became effective as of January 2014 ("Flightcrew Member Duty," 2012). The rest requirements found in Part 117 are applicable to all certificate holders operating under 14 CFR Part 121 (Part 121), which includes most passenger airline pilots in the United States. As of January 2015, cargo carrier carriers operating under Part 121 are exempt from Part 117.

\section{Problem Statement}

This study explores the perceptions of self-identified FAA-certified pilots on effects of Part 117 on safety, alertness and fatigue three months after the rule became effective. It is widely accepted that shared beliefs and perceptions are linked to safety culture (Cooper, 2000). The researchers regard pilot perceptions of Part 117 and its elements as an important indication of the adequacy and success of 
the crew rest requirements. Using a Likert-scale survey, self-identified pilots certified by the FAA were asked about the perceived impact of the crew rest requirements on overall safety, including the ability to operate the aircraft safely and adapt to an adequate sleep cycle, as well as alertness and fatigue level.

The researchers decided to include a question to determine whether pilots were in favor of including cargo pilots in Part 117 specifically to establish how the pilot community perceived this exclusion. This question was included in response to a press release by the union representing UPS pilots calling for an end of the Part 117 exception for cargo carriers (Independent Pilots Association, 2014).

\section{Literature Review}

The purpose of this literature review was to define fatigue and its impact on safety in aviation, discuss the development and scope of the crew rest regulations, and provide an overview of prior studies on pilot fatigue perception in aviation.

\section{Defining Fatigue and its Impact on Safety in Aviation}

Most people have experienced fatigue in their lives at home, work, or school. Fatigue may generally be defined as a reduction in the ability to complete work, and may occur due to physically or mentally demanding tasks.

Caldwell (2005) stated that commercial airline pilots are "constantly confronted with long duty days, early departures, late arrival, and non-standard work hours that include night duty and rotating schedules" (p. 88) and found that these factors could result in sleep loss, which may contribute to fatigue. Pilot fatigue is a well-recognized concern in the airline industry. The European Cockpit Association (2012) reported that $85 \%$ of pilots surveyed in Austria and Denmark indicated operating aircraft while being too fatigued. A survey of Portuguese airline pilots found that $91.4 \%$ of participants revealed having made errors in the cockpit due to fatigue (Reis, Mestre, \& Canhão, 2013).

There are many definitions of fatigue. In the context of aviation, the International Civil Aviation Organization [ICAO] (2013) defines fatigue as:

A physiological state of reduced mental or physical performance capability resulting from sleep loss or extended wakefulness, circadian phase, or workload (mental and/or physical activity) that can impair a crew member's alertness and ability to safely operate an aircraft or perform safety-related duties (p. 2). 
ICAO's definition of fatigue emphasized important factors that affect a pilot's ability to safely operate an aircraft, such as extended wakefulness, workload, and circadian phases. The FAA (2009) described fatigue and its impact on safety as "a condition characterized by increased discomfort with lessened capacity for work, reduced efficiency of accomplishment, loss of power or capacity to respond to stimulation, and is usually accompanied by a feeling of weariness and tiredness" (p. 2). Increased discomfort is a perception or feeling. Therefore, perception of fatigue is part of measuring fatigue.

There is no universal answer to how fatigue can be avoided, but Konz (1990) suggested that "Fatigue is reduced by (1) preventing it in the first place, and (2) curing it with rest," (p. 293) two principles that are evident in the Part $117 \mathrm{crew}$ rest requirements.

Pilot associations in Europe and North America (European Cockpit Association, 2012) have identified pilot fatigue as a major safety issue for their members. ALPA (2008a) has long worked on lobbying and advocating for improved crew rest requirements to mitigate the impact of fatigue on pilot performance. In 2008, ALPA stated that "The flight and duty rules and regulation in the United States and Canada are archaic, were written decades ago and were based on aircraft types and operations that were in existence then." (p. iii), urging regulators to act.

\section{Previous Studies on Pilot Fatigue Perception in Aviation}

Co, Gregory, Johnson and Rosekind (1999) found that regional airline pilots identified long duty days, multiple flight legs, and short rest periods as factors contributing to fatigue. Bourgeois-Bourgrine, Cabon, Gounelle, Mollard and Coblentz (2003) found in a survey of 739 airline pilots that both long-haul and short-haul pilots perceived sleep loss as principal factor for fatigue.

\section{Development and Scope of Crew Rest Regulations}

Managing human fatigue has been an item on NTSB's "Most Wanted" list since its first publication in 1990 (U.S. Department of Transportation [DOT], 2009). In June 2008, the NTSB issued a recommendation urging the FAA to "develop guidance...for operators to establish fatigue management systems" (p. $10)$.

In 2009, the Office of Inspector General (OIG) announced an audit of FAA regulations and airline policies in regard to crew rest requirements (DOT, 2009). In 2010, Congress passed the Airline Safety and Federal Aviation Administration Extension Act of 2010, which is also known as the 1,500-hour rule. The act 
contained provisions about pilot fatigue in Section 212. In this section, Congress urged the FAA to "issue regulations . . . to specify limitation on the hours of flight and duty time" (p. 2362) considering factors such as time of day, number of takeoffs and landings, number of time zones crossed as well as research on fatigue (Airline Safety and Federal Aviation Administration Extension Act of 2010). The act also contained provisions requiring Part 121 carriers to submit Fatigue Risk Management Plans to the FAA.

The FAA accelerated its work on crew rest requirements and issued a notice for proposed rulemaking in 2010 (FAA, 2010). The final rule was published in the Federal Register on January 4, 2012. It became effective two years later on January 4, 2014 ("Flightcrew Member Duty,” 2012).

Part 117 consists of thirteen sections related to crew rest that are shown in Table 1. The elements of the regulations included fitness for duty requirements, the introduction of required Fatigue Risk Management Systems (FRMS) for airlines, flight time limitations, the introduction of flight duty periods, cumulative flight time and flight duty period limits, and required rest periods ("Flightcrew Member Duty," 2012). The following section explains six major sections contained in Part 117.

Fitness for Duty. The fitness for duty requirements introduced in Part 117 instruct individual flight crew members to affirm that they are prepared and rested enough to perform their duty ("Flightcrew Member Duty," 2012).

Fatigue Risk Management System. The definition of a FRMS is "the planning and control of the working environment, in order to minimize, as far as is reasonably practicable, the adverse effects of fatigue on workforce alertness and performance" (Gander et al., 2011, p. 574). Gander et al. (2011) also determined that comprehensive FRMS include both fatigue prevention and fatigue mitigation strategies. Under Part 117, airlines need to establish a FRMS to better manage fatigue-related risk factors ("Flightcrew Member Duty," 2012).

Flight Time Limitations. In Part 117, the FAA defined limits for maximum flight time. For 2-pilot crews, a pilot cannot be scheduled to fly more than 8 hours between midnight to 5am, 9 hours between 5 am and 7:59 pm, and 8 hours between $8 \mathrm{pm}$ and midnight. Flight time limits of 13 hours and 17 hours apply for 3-pilot and 4-pilot crews respectively ("Flightcrew Member Duty," 2012).

Flight Duty Periods. The FAA defined limits for flight duty period durations ranging between 9 and 14 hours based on time of start and number of flight segments flown (“Flightcrew Member Duty," 2012). 


\section{Table 1}

\section{Elements of Part 117 Contained in the Federal Register}

\begin{tabular}{|c|c|}
\hline Section & Description \\
\hline$\S 117.5$ Fitness for duty & $\begin{array}{l}\text { Flightcrew members need to affirmatively state that he or she is fit for duty, defined as rested } \\
\text { and prepared to perform his or her duties }\end{array}$ \\
\hline$\S 117.7$ Fatigue risk management system & $\begin{array}{l}\text { Airlines must have a FRMS or equivalent system in place, which must include pre-defined } \\
\text { components }\end{array}$ \\
\hline $\begin{array}{l}\S 117.7 \text { Fatigue education and awareness } \\
\text { training program }\end{array}$ & $\begin{array}{l}\text { Airlines must develop and implement a fatigue education and awareness training program for } \\
\text { crewmembers, crew schedulers, operations managers and personnel overseeing operations or } \\
\text { scheduling }\end{array}$ \\
\hline$\S 117.11$ Flight time limitation & $\begin{array}{l}\text { The FAA specified time limits for flight duty periods, depending on number of flightcrew } \\
\text { members present in the cockpit, time of report and number of segments }\end{array}$ \\
\hline $\begin{array}{l}\S 117.13 \text { - Flight duty period: } \\
\text { Unaugmented operations }\end{array}$ & $\begin{array}{l}\text { In addition to flight duty period limitations, the FAA introduced the term "unaugmented } \\
\text { operations", under which the flight duty period is based on local time at the theater in which the } \\
\text { flightcrew member was last acclimated. The maximum flight duty period is reduced by } 30 \\
\text { minutes for unaugmented operations. }\end{array}$ \\
\hline$\S 117.15$ Flight duty period: Split duty & $\begin{array}{l}\text { Under certain conditions and for unaugmented operations only, if a flightcrew member is } \\
\text { provided with a rest opportunity (an opportunity to sleep) in a suitable accommodation during } \\
\text { his or her flight duty period, the time that the flightcrew member spends in the suitable } \\
\text { accommodation is not part of that flightcrew member's flight duty period }\end{array}$ \\
\hline $\begin{array}{l}\S 117.17 \text { Flight duty period: Augmented } \\
\text { flightcrew }\end{array}$ & $\begin{array}{l}\text { For flight operations conducted with an acclimated augmented flightcrew, no certificate holder } \\
\text { may assign and no flightcrew member may accept an assignment if the scheduled flight duty } \\
\text { period will exceed specified limits }\end{array}$ \\
\hline$\S 117.19$ Flight duty period extension & $\begin{array}{l}\text { Under unforeseen operational circumstances, flight duty period extensions of up to } 2 \text { hours may } \\
\text { apply }\end{array}$ \\
\hline$\S 117.21$ Reserve status & The FAA defined time limits for flightcrew member reserve status \\
\hline$\S 117.23$ Cumulative limitation & $\begin{array}{l}\text { Flightcrew member's total flight time cannot exceed: (1) } 100 \text { hours in any } 672 \text { consecutive } \\
\text { hours or (2) } 1,000 \text { hours in any } 365 \text { consecutive calendar day period. Flightcrew member's total } \\
\text { Flight Duty Period cannot exceed: (1) } 60 \text { flight duty period hours in any } 168 \text { consecutive hours } \\
\text { or (2) } 190 \text { flight duty period hours in any } 672 \text { consecutive hours. }\end{array}$ \\
\hline$\S 117.25$ Rest period & $\begin{array}{l}\text { Before beginning any reserve or duty period a flightcrew member must be given at least } 30 \\
\text { consecutive hours free from all duty within the past } 168 \text { consecutive hour period. If the } \\
\text { flightcrew member travels more than } 60 \text { degrees longitude or is away for more than } 158 \\
\text { consecutive hours, a rest period of } 56 \text { hours or three physiological nights' rest must be provided. } \\
\text { Flightcrew members rest time can be reduced to } 10 \text { hours with } 8 \text { hours of uninterrupted sleep } \\
\text { opportunity if travel is within } 60 \text { degrees of longitude and cumulative limitations are not } \\
\text { exceeded. }\end{array}$ \\
\hline$\S 117.27$ Consecutive nighttime operations & $\begin{array}{l}\text { A certificate holder may schedule and a flightcrew member may accept up to five consecutive } \\
\text { flight duty periods that infringe on the window of circadian low if the certificate holder provides } \\
\text { the flightcrew member with an opportunity to rest in a suitable accommodation during each of } \\
\text { the consecutive nighttime flight duty periods. }\end{array}$ \\
\hline
\end{tabular}

$\S 117.29$ Emergency and government Special regulations exist for emergency and government sponsored operations sponsored operations

\section{Note. From "Flightcrew Member Duty and Rest Requirements" 77 Fed. Reg. 329 (January 4, 2012) (to be codified at 14 C.F.R. pts. 117, 119, 121)}


Cumulative Flight Time and Flight Duty Period Limits. No pilot is permitted to fly more than 100 hours in any 627 consecutive hour period or 1,000 hours in any consecutive 365 calendar day period. Additionally, the total cumulative flight duty period cannot exceed 60 hours in any 168 consecutive hour time period or 190 flight duty hours in any 672 consecutive hour period ("Flightcrew Member Duty," 2012).

Required Rest Periods. Pilots must have a rest period of at least 30 consecutive hours within the past 168 consecutive hour period. Part 117 also contains provisions for travel exceeding 60 degrees of longitude, in which case an extended 56-hour rest period "encompassing three physiological nights' rest" must be provided. If no travel exceeding 60 degrees of longitude takes place, a rest period of 10 hours including 8 hours of uninterrupted sleep opportunity must be provided prior to any duty period ("Flightcrew Member Duty," 2012).

\section{Method}

An online survey was sent to subscribers of the Flight Safety Information Newsletter, maintained by Curt Lewis and Associates LLC. This newsletter was selected primarily due to its large number of subscribers who are pilots. Over a period of three weeks in March and April 2014, 132 self-identified pilots participated in the study. For the analysis, 92 respondents completed all survey questions and, therefore, were selected to be included in the study.

Of these 92 pilots, 88 identified as male and 4 as female. When asked about their highest level of pilot certification, 89 respondents indicated having a FAA Air Transport Pilot Certificate; one participant indicated having a FAA Commercial certificate; and two participants chose "Other." For type of operations flown, 68\% of participants indicated that they fly under Part 121 Passenger Service, 17\% under Part 91, 12\% under Part 121 Cargo Service, and 3\% under Part 135, as shown in Figure 1.

Prior to the main survey questions, participants were asked to rate their knowledge of the changes contained in Part 117 ranging from "I have not heard about it" to "I have heard about it and I am very familiar with it." Five participants who chose "I have not heard about it" were directed to the end of the survey and thanked for their participation. 


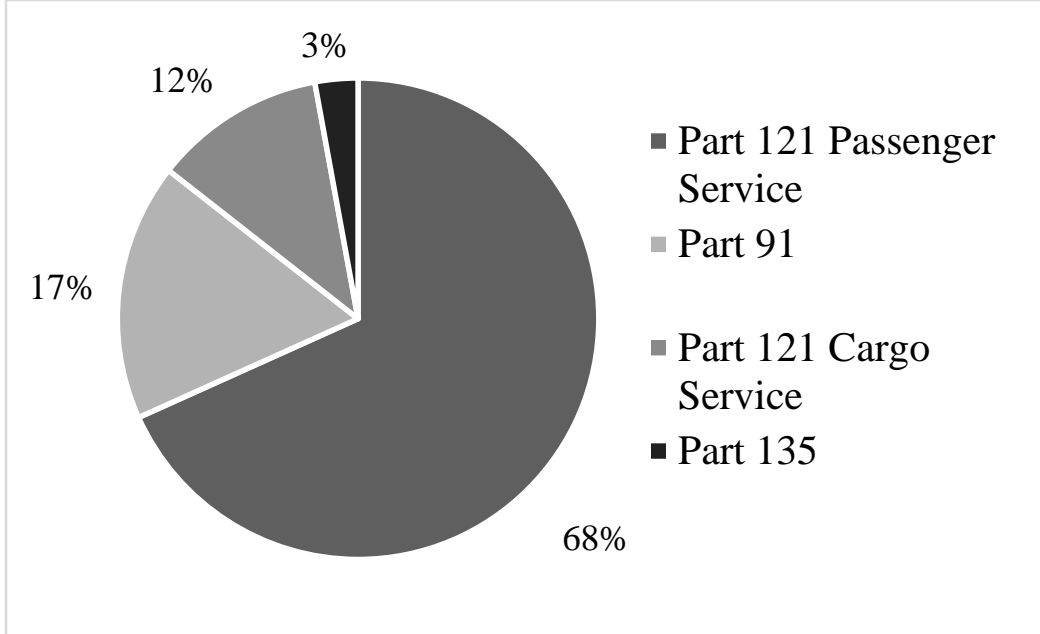

Figure 1. Type of operations flown by survey participants

Table 2 shows the questions contained in the survey. The first question contained five sub-items. Participants were asked to choose answers on a scale ranging from $1-$ strongly negative to 5 - strongly positive. The second question asked participants if they thought that cargo operations should be included in the crew rest regulations. Participants were asked to choose answers on a scale ranging from 1 - strongly disagree to 5 - strongly agree. The third question asked for comments on the crew rest regulations.

Table 2

Representation of Survey Structure and Survey Questions

\begin{tabular}{|c|c|c|c|}
\hline$\#$ & Question & Item & Type of Answer \\
\hline 1 & $\begin{array}{l}\text { Please indicate how you feel } \\
\text { the following items have been } \\
\text { impacted on a personal level by } \\
\text { the new regulations in } 14 \\
\text { C.F.R. Part } 117\end{array}$ & $\begin{array}{l}\text { Overall Safety } \\
\text { Ability for pilots to operate the aircraft } \\
\text { safely } \\
\text { Overall pilot alertness } \\
\text { Ability for pilots to adapt to an adequate } \\
\text { sleep cycle } \\
\text { Overall pilot fatigue level }\end{array}$ & $\begin{array}{l}\text { Likert-scale: } \\
1 \text { - strongly negative to } \\
5 \text { - strongly positive }\end{array}$ \\
\hline 2 & $\begin{array}{l}\text { Do you think that Cargo } \\
\text { Operations should be included } \\
\text { in } 14 \text { C.F.R Part } 117 ?\end{array}$ & & $\begin{array}{l}\text { Likert-scale: } \\
1 \text { - strongly disagree to } \\
5 \text { - strongly agree }\end{array}$ \\
\hline 3 & $\begin{array}{l}\text { Do you have any additional } \\
\text { comments regarding how the } \\
\text { new regulations in } 14 \text { C.F.R. } \\
\text { Part } 117 \text { will affect you } \\
\text { personally? }\end{array}$ & & Open-ended \\
\hline
\end{tabular}


The survey questions were developed by the researchers, then revised with the help of an expert panel to assure face validity. The expert panel consisted of three university aviation professors who have Part 121 flight experience as well as extensive knowledge of both survey creation and survey methodology.

The 13 Likert-scale questions contained in sections one through three were analyzed for internal consistency with Cronbach's $\alpha$, which resulted in a value of $\alpha$ $=0.901$. A Cronbach's $\alpha$ of $\geq 0.6$ is generally accepted to be robust. For the analysis of the 49 open-ended comments, the researchers developed a coding scheme to identify recurring themes. The coding process was independently performed by two researchers using QSR International's NVivo 10 qualitative data analysis software. Table 3 shows the ten different codes that were assigned to the open-ended answers. The coding results were compared and the agreement rate between the two raters was $94 \%$, as provided by the qualitative data analysis software.

Table 3

Codes and Definitions Used in Qualitative Analysis of Open-Ended Comments

\begin{tabular}{ll}
\hline Code & Description \\
\hline Cargo & Participant mentioned cargo in comment \\
Improve safety & Participant mentioned improved safety \\
Less fatigued & Participant mentioned being less fatigued \\
Less rest & Participant mentioned getting less rest \\
Less safe & Participant mentioned being less safe \\
Longer flight time & Participant mentioned having to fly more \\
More fatigued & Participant mentioned feeling more fatigued \\
Negative & Participant mentioned feeling negatively about the new regulations \\
Positive & Participant mentioned feeling positively about the new regulations \\
Split day & Participant mentioned the problem of split day and split shift \\
\hline
\end{tabular}

\section{Results}

Results from each of the three survey questions are discussed. Once again, it is important to mention that the rule became effective in January 2014 and that the survey was administered in March and April 2014.

\section{Perceptions of the Regulations Impact}

The five sub-question in this section were used to measure perceptions of the impact Part 117 had on ability to operate the aircraft safely, alertness, ability to adapt to an adequate sleep cycle and fatigue level. Table 4 summarizes the results. 
Pilots perceived that Part 117 impacted safety positively, with 32 (35\%) respondents choosing "Slightly Positive" and 8 (9\%) respondents choosing "Strongly Positive." Sixteen (17\%) felt a "Slightly Negative" impact and 11 (12\%) felt a "Strongly Negative" impact on overall safety at a personal level. Twenty-five $(27 \%)$ of respondents felt no impact on overall safety at a personal level.

Pilots indicated positive perceptions of the impact on overall level of fatigue. Twenty-nine (32\%) participants felt a slightly positive impact of Part 117 on their overall fatigue level and three (3\%) participants felt a strongly positive impact. Sixteen (17\%) participants indicated a slight negative impact on their fatigue level and $13(14 \%)$ indicated a strongly negative impact. Thirty-one (33\%) participants felt no impact of Part 117 on their overall fatigue level.

Overall, pilot perceptions on these five items were mixed, with many pilots indicating that they perceived no positive or negative impact.

Table 4

Perceptions of the Regulations' Impact on Personal Level

\begin{tabular}{llllllll}
\hline Question & $\begin{array}{l}\text { Strongly } \\
\text { Negative }\end{array}$ & $\begin{array}{l}\text { Slightly } \\
\text { Negative }\end{array}$ & None & $\begin{array}{l}\text { Slightly } \\
\text { Positive }\end{array}$ & $\begin{array}{l}\text { Strongly } \\
\text { Positive }\end{array}$ & Mean & SD \\
\hline Overall safety & $12 \%$ & $17 \%$ & $27 \%$ & $35 \%$ & $9 \%$ & 3.11 & 1.162 \\
$\begin{array}{l}\text { Ability to operate } \\
\text { the aircraft safely }\end{array}$ & $4 \%$ & $22 \%$ & $35 \%$ & $30 \%$ & $9 \%$ & 3.17 & 1.012 \\
$\begin{array}{l}\text { Overall pilot } \\
\text { alertness }\end{array}$ & $8 \%$ & $21 \%$ & $38 \%$ & $29 \%$ & $4 \%$ & 3.02 & 0.994 \\
$\begin{array}{l}\text { Ability to adapt to } \\
\text { an adequate sleep } \\
\text { cycle }\end{array}$ & $12 \%$ & $15 \%$ & $47 \%$ & $23 \%$ & $3 \%$ & 2.90 & 0.995 \\
$\begin{array}{l}\text { Overall pilot } \\
\text { fatigue level }\end{array}$ & $14 \%$ & $17 \%$ & $34 \%$ & $32 \%$ & $3 \%$ & 2.92 & 1.092 \\
\hline
\end{tabular}

\section{Perceptions on Inclusion of Cargo Operators}

Fifty-seven (62\%) participants strongly agreed and 16 (17\%) agreed with the statement that cargo operators should be included under Part 117, compared to seven participants $(8 \%)$ disagreeing or strongly disagreeing with the statement. Eleven $(12 \%)$ participants neither agreed or disagreed with the statement. Figure 2 summarizes the results. 


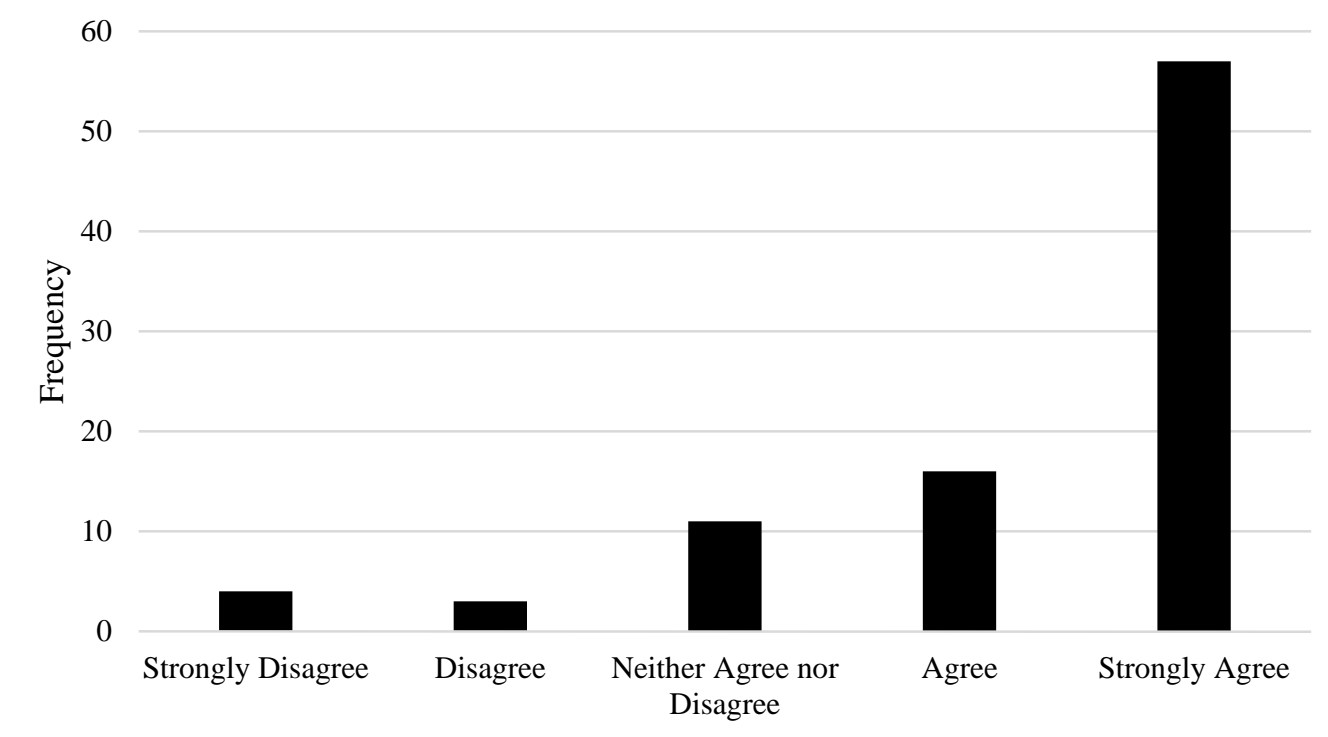

Figure 2. Frequency of responses to inclusion of cargo carriers.

Only $12 \%$ of the respondents identified themselves as cargo pilots, while a total $79 \%$ of the pilots agreed that cargo carriers should be included in Part 117. Of the twelve cargo pilots answering the survey, nine strongly agreed and one agreed about including cargo pilots in Part 117 . One cargo pilot strongly disagreed and one cargo pilot answered "neither agree or disagree."

\section{Open-Ended Survey Responses}

Forty-nine (53\%) of the 92 participants used the opportunity to provide comments about the impact of the regulations on a personal level. The researchers analyzed these responses by assigning ten different codes to the comments based on topics mentioned. The frequency of each code is shown in Figure 3. As mentioned earlier, the coding agreement rate was $94 \%$, which is considered high. 


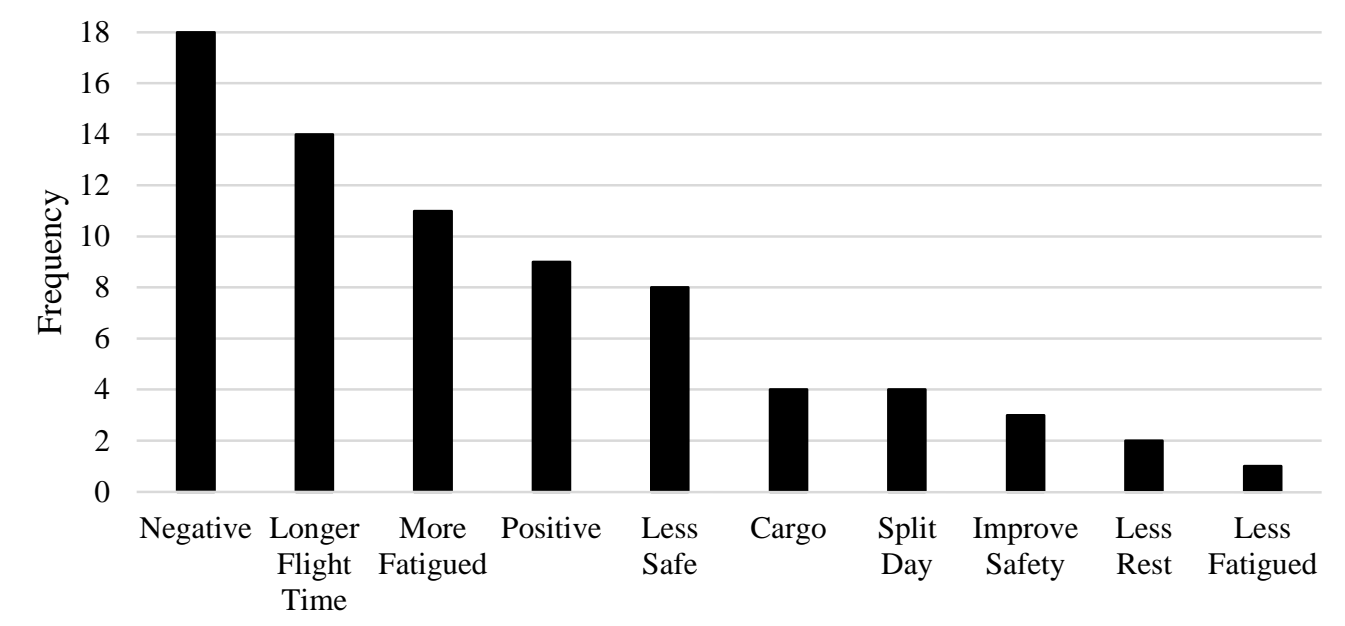

Figure 3. Frequency of codes in comments.

For the qualitative analysis, common themes were identified. The results revealed that generally negative perceptions about the crew rest regulations were mentioned eighteen times, and generally positive perceptions nine times. Specific comments, both positive and negative, are presented separately under headings such as "improve safety" and "longer flight time." For safety, eight respondents indicated "less safe" and three respondents indicated "improve safety." For fatigue, 11 respondents indicated "more fatigue," and one respondent indicated "less fatigue."

These comments lead to a general impression that the crew rest changes are more often viewed negatively than positively among the pilots providing comments. It is important to note that specific negative or positive comments such as "more fatigued" or "improve safety" are not a subset of general negative or positive comments. Individual comments may have had multiple codes assigned.

\section{Discussion}

Perception of self-identified FAA-certified pilots on effects of Part 117 on safety, alertness and fatigue was addressed in the first survey question. The results of this first survey question showed that pilots perceived a mixed impact of Part 117 on safety, alertness and fatigue, with between $27 \%-47 \%$ of pilots picking a neutral position. The researchers believe that this high percentage of neutral responses may be attributed to the timing of the survey, which was sent out over a two-week period in March/April 2014, only months after the rule became effective in January 2014. 
Pilot perceptions on including cargo carriers in the Part 117 regulations were asked in the second survey question. The results for this second question showed that pilots strongly favor an inclusion of cargo carriers under Part 117, indicating that the surveyed pilots had strong opinions about the exclusion of cargo pilots.

The third research question gave participating pilots the opportunity to provide open-ended comments. Eighteen out of 49 open-ended comments indicated negative reactions to the crew rest requirements, while positive sentiments were mentioned nine times. Selected negative comments are discussed in order to highlight some of the perceived shortcomings of Part 117.

Fourteen respondents mentioned that they were now flying more hours under Part 117. One pilot stated that "While this [the crew rest regulations] was done to combat fatigue, I feel like it has done the opposite in many ways. I can now fly up to nine block hours versus eight, depending upon check in time and number of legs. I can also routinely fly six days in a row, and I never could do that under the previous rules. The cumulative aspects of fatigue are dangerous, but they are overlooked completely."

Four participants mentioned the problem of split days or split shifts. Although the crew rest requirements prescribe a 10-hour rest period, including 8 hours of uninterrupted sleep opportunity between two separate flight duty periods, the rest time can be scheduled during any time of day or night ("Flightcrew Member Duty," 2012). Pilots mentioned that scheduling a rest period during day-time did not afford them with an adequate rest opportunity between two shifts. In a split shift day, pilots may be scheduled to fly two long-haul flights within a 24-hour period. To illustrate this split-shift scenario, a hypothetical example was developed and is shown in Figure 4.

The rest period between two separate flight duty periods can be reduced to 10 hours with 8 hours of uninterrupted sleep opportunity if travel does not exceed $60^{\circ}$ of longitude, a reduction from 56 hours or three nights when travel exceeds $60^{\circ}$ of longitude. In the scenario shown in Figure 4, a pilot is scheduled to fly from the East Coast of the U.S. to Brazil for the first flight duty period. After completing the first duty period, an airline could hypothetically schedule the same pilot for a trip to Europe on the same day of his return, after only 10 hours of rest time that would occur during daytime. In this scenario, the split between shifts occurs on day 5 the Split Day. 
Rest time can be reduced to 10 hours

with 8 hours of uninterrupted sleep

opportunity if travel is within 60

degrees of longitude

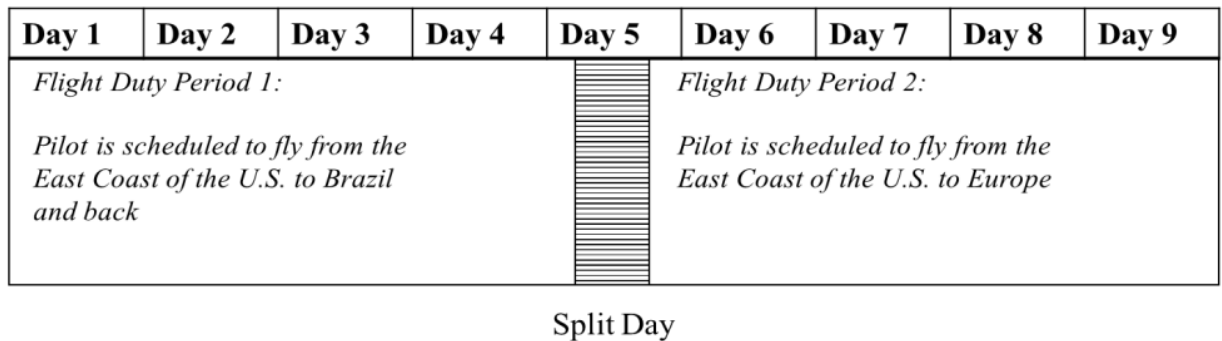

Figure 4. A hypothetical split-shift scenario

The opinion that cargo operators should be included in the regulations was another recurring theme, explicitly mentioned by four pilots in the open-ended comments section. One pilot stated that "When cargo operators were cut out of the 117 rules, the industry failed to protect the pilots and public on the ground. To not be covered by the new 117 rules is a slap in the face and to say my life has no value."

A second pilot stated that "a hull loss [of a cargo aircraft] into a school/freeway (you name it) would be equally disastrous as a passenger aircraft."

The analysis of the open-ended comments revealed negative perceptions among pilots about the lack of cargo carrier inclusion in the rest requirements and the problem of split shifts, where pilots were scheduled to operate two long-haul flights within a 24-hour period.

\section{Limitations}

A caveat of the findings is that the survey was conducted less than four months after the effective date of Part 117. It is possible that pilots and airlines had not completed their adjustments to accommodate the rule in an operationally feasible manner at that point in time. The survey may need to be repeated to measure pilot perceptions longitudinally to better understand the effect of Part 117 on perceived safety and level of fatigue.

It should also be noted that a response bias may be present as the results of this survey may not be representative of the general pilot population. In addition, a 
known response bias for this of type of survey is that participants with strong opinions may be overrepresented, especially in the open-ended comments.

\section{Conclusion}

This study explored the perceptions of self-identified FAA-certified pilots on effects of Part 117 on safety, alertness and fatigue within months after the rule became effective. Pilots were asked about their perception of including cargo pilots under Part 117.

Pilot perceptions were mixed on the safety, fatigue and alertness items. Responses for many items were slightly positive, but a large percentage of respondents were neutral, which the researchers contribute to the relative recent effectiveness of Part 117 at the time of survey administration in March/April 2014.

Seventy-nine percent of pilots responded that they were very strongly or strongly in favor of including cargo pilots under Part 117. This apparent concern about the exclusion of cargo carriers in the crew rest regulations was also reflected in the open comments, where four pilots explicitly mentioned the issue.

This exploratory study into perceptions of self-identified pilots shortly after the implementation of these crew rest requirements can serve as a stepping stone for future research. Follow-up studies in years after the implementation of Part 117 and an increased sample size may help to measure pilot perceptions longitudinally. It is also hoped that the open-ended comments presented in this study can help researchers to develop further research questions based on the issues mentioned by pilots. 


\section{References}

Air Line Pilot Association. (2008a). Air line pilot's guide to fatigue. Retrieved from http://www3.alpa.org/portals/alpa/fatigue/MagazineInsert102008_FatigueGuide.pdf

Air Line Pilot Association. (2008b). Airline pilot fatigue still front-and-center safety risk. Retrieved from http://www2.alpa.org/DesktopModules/ALP A_Documents/ALPA_DocumentsView.aspx?itemid=13745\&ModuleId=1 2565\&Tabid $=256$

Airline Safety and Federal Aviation Administration Extension Act of 2010, S. 2348. $111^{\text {th }}$ Cong. (2010). Retrieved from https://www.congress.gov/111/plaws/publ216/PLAW-111publ216.pdf

Bourgeois-Bougrine, S., Carbon, P., Gounelle, C., Mollard, R., and Coblentz, A. (2003). Perceived fatigue for short-and long-haul flights: A survey of 739 airline pilots. Aviation, Space, and Environmental Medicine, 74(10), 10721077. Retrieved from http://www.ingentaconnect.com/content/asma/asem /2003/00000074/00000010/art00010

Caldwell, J. A. (2005). Fatigue in aviation. Travel Medicine and Infectious Disease, 3(2), 85-96. doi:10.1016/j.tmaid.2004.07.008

Co, E. L., Gregory, K. B., Johnson, J. M., \& Rosekind, M. R. (1999). Crew factors in flight operations. 11; A survey of fatigue factors in regional airline operations. Moffett Field, California: NASA

Cooper, M. D. (2000). Towards a model of safety culture. Safety Science, 36(2), 111-136. doi:10.1016/S0925-7535(00)00035-7

European Cockpit Association. (2012). Pilot fatigue: Barometer. Retrieved from https://www.eurocockpit.be/sites/default/files/eca_barometer_on_pilot_fat igue_12_1107_f.pdf

Federal Aviation Administration. (2010). Flightcrew member duty and rest requirements. Retrieved from http://www.faa.gov/regulations_policies/rul emaking/recently_published/media/FAA_2010_22626.pdf

Flightcrew Member Duty and Rest Requirements, 77 Fed. Reg. 329 (2012, January 4) (to be codified at 14 C.F.R. pts. 117, 119, 121).

Gander, P., Hartley, L., Powell, D., Cabon, P., Hitchcock, E., Mills, A., \& Popkin, S. (2011). Fatigue risk management: Organizational factors at the regulatory and industry/company level. Accident Analysis \& Prevention, 43(2), 573-590. doi:10.1016/j.aap.2009.11.007 
Konz, S. A. (1990). Work design: Industrial ergonomics. Worthington, Ohio: Pub. Horizons.

International Civil Aviation Organization. (2013). Excerpts of fatigue management-related provisions from Annex 6 Part I. Retrieved from http://www.icao.int/safety/fatiguemanagement/FRMS\%20Tools/Amendm ent $\% 2037 \% 20$ for\%20FRMS\%20SARPS\%20(en).pdf

National Transportation Safety Board. (2008). Safety recommendation A-08-44 and -45. Retrieved from http://www.ntsb.gov/safety/safetyrecs/recletters/A08_44_45.pdf

National Transportation Safety Board. (2010). Loss of control on approach, Colgan Air, Inc., operating as Continental Connection flight 3407, Bombardier DHC-8-400, N200WQ. NTSB/AAR-10/01 PB2010-910401, 2010. Retrieved from http://www.ntsb.gov/investigations/AccidentReports /Reports/AAR1001.pdf

National Transportation Safety Board. (2014). Crash during a nighttime nonprecision instrument approach to landing, UPS Flight 1354, Airbus A300-600, N155UP, Birmingham, Alabama, August 14, 2013. Retrieved from http://www.ntsb.gov/investigations/AccidentReports/Reports/AAR1 402.pdf

Office of the Inspector General. (2011). Audit Report: FAA and industry are taking action to address pilot fatigue, but more information on pilot commuting is needed. Retrieved from https://www.oig.dot.gov/sites/defaul t/files/FAA\%20Crew\%20Rest\%20and\%20Fatigue\%20Report\%5E09-1211.pdf

Independent Pilots Association. (2014). UPS pilots call for end of Part 117 carveout on anniversary of fatigue crash. Retrieved from http://www.ipapilot.org/press.asp?id=2418

Reis, C., Mestre, C., \& Canhão, H. (January 01, 2013). Prevalence of fatigue in a group of airline pilots. Aviation, Space, and Environmental Medicine, 84(8), 828-33. doi:10.3357/ASEM.3548.2013

U.S. Department of Transportation. (2009). Audit announcement - Review of FAA regulations and airline policies regarding crew rest requirements and fatigue issues Federal Aviation Administration project no. 09A3010A000. Retrieved from https://www.oig.dot.gov/sites/default/files/ Pilot_Fatigue_Announcement_Letter_issued.pdf 